PRZEGLĄD NAUK HISTORYCZNYCH 2017, R. XVI, NR 2

http://dx.doi.org/10.18778/1644-857X.16.02.05

Ewelina Maria Kostrzewska

UNIWERSYTET ŁÓDZKI"

\title{
Reportaż na koniec wieku. Europejskie podróże gospodarcze Cecylii hr. Plater-Zyberkówny w świetle „Kroniki Rodzinnej” (1899 r.)
}

Streszczenie. Artykuł przygotowany został na podstawie „Kroniki Rodzinnej”, dwutygodnika wydawanego od 1867 r. w Warszawie. Adresowany do ziemiaństwa oraz inteligencji miał charakter literacko-społeczny i pamiętnikarsko-podróżniczy, często podejmował sprawy tzw. kwestii kobiecej. W czasie swojego istnienia zachodziły w nim przekształcenia programowe, a po wyciszeniu sporów ideologicznych w latach osiemdziesiatych XIX w. redakcja skupiała uwage na sprawach domowych i wychowawczych. Płynac $z$ umiarkowanym nurtem ruchu równouprawnienia kobiet, propagowała ich zawodowe wykształcenie oraz aktywność.

W 1899 r. naczelna redaktorką i wydawczynia pisma została Cecylia hr. Plater-Zyberkówna, która w swoich poglądach asymilowała ziemiańskie, zachowawcze ideały $z$ inteligenckim modelem otwartego katolicyzmu. W okresie jej prawie rocznej kadencji „Kronikę Rodzinną” przekształcano w popularne „Czasopismo dla Rodzin Katolickich". Sama redaktorka zaś zainaugurowała i zamknęła pełnienie swoich funkcji drukowanym w odcinkach reportażem podróżniczym.

Taką nowoczesna forma dziennikarskiego sprawozdania wchodziła w trudno dostępny dla kobiet świat mediów, samodzielnych, szybkich podróży i pracy zawodowej. Sprowadzajacc do wspólnego mianownika poszukiwania w Europie żeńskich szkół gospodarczych, zdawała relację z ich cywilizacyjnej kondycji. W nasyconych religijna aksjologia opisach przedstawiała czytelnikom własne refleksje i społeczne konteksty emancypacji kobiet.

W poincie podróżniczej relacji powracała na polski grunt $z$ idea solidaryzmu społecznego; pogodzenia aspiracji kobiet $z$ religią. Więź społeczna w sposób szczególny łączyć miała kobiety z ziemiańskich elit i chłopskiej wsi, a szkoły gospodarcze otwierać im pola aktywności i pracy. W myśl reguł prasowego reportażu

* Wydział Filozoficzno-Historyczny, Instytut Historii, Katedra Historii Polski XIX w., e-mail: ewekostrzewska@o2.pl. 
opowieść Plater-Zyberkówny odsłaniała europejska rzeczywistość końca XIX w. $\mathrm{w}$ jej subiektywnych obrazach widzianych $\mathrm{z}$ perspektywy arystokratki i naczelnej katolickiej „Kroniki Rodzinnej”.

Słowa kluczowe: czasopisma katolickie, „Kronika Rodzinna”, reportaż, Cecylia hr. Plater-Zyberkówna, prasa Królestwa Polskiego, podróże, szkoły gospodarcze, Europa.

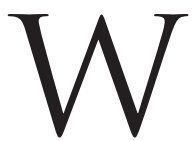

kulturze europejskiej reportaż, jako odrębne zjawisko piśmiennicze, wyrastał z osiemnastowiecznych opisów podróży rozpowszechnianych $\mathrm{w}$ prasie. Jego rozkwit w kolejnym stuleciu był zbieżny z przemianami cywilizacyjnymi, które nadawały nowa jakość i prędkość obiegowi informacji oraz pokonywaniu przestrzeni.

W końcu wieku XIX wzrastało znaczenie reportażu również w prasie polskiej ${ }^{1}$. Wraz z rozwojem komunikacji i komunikowania zdobywał on rangę nowoczesnego środka przekazu². Coraz częściej też ten typ piśmiennictwa, $z$ pogranicza dziennikarskiej informacji, publicystyki i literatury, uprawiały kobiety. Relacje $z$ samodzielnych wędrówek po świecie stawały się modnym trendem i symptomem emancypacji. Wcześniejsze, właściwe elitom zjawisko Grand Tour, równolegle $\mathrm{z}$ rozwojem turystyki, przybierało formy podróży krótszych, zadaniowych i sprawozdawczych. Często towarzyszył im kontekst edukacji kulturowej, wzmocniony rezerwowanym dla reportażu autentyzmem, dynamiką oraz aktualnościa zdarzeń i waga problemów, znanych autorom $z$ własnych doświadczeń.

W taką reporterską wędrówkę w 1898 r. udała się Cecylia hr. Plater-Zyberkówna (1853-1920), znana wówczas publicystka, wybitna pedagożka, założycielka żeńskich szkół zawodowych w Królestwie Polskim ${ }^{3}$. Należąca do ukrytego ruchu zgromadzeń zakonnych tworzonych przez kapucyna Honorata Koźmińskiego (1829-1916), swoją relację $z$ wyjazdu w roku 1899 zamieściła w „Kronice Rodzinnej”, optujacej za wartościami religijnymi.

Pismo miało już wówczas długa tradycję wydawnicza z przekształceniami programowymi. Założone w $1867 \mathrm{r}$. przez Aleksandrę Borkowską było adresowanym do ziemiaństwa oraz inteligencji

${ }^{1}$ M. Wojtak, Gatunki prasowe, Lublin 2004, s. 268 i n.

2 Por. A. Mattelart, M. Mattelart, Teoria komunikowania, Warszawa 2001.

3 T. Górski, Plater-Zyberk Cecylia, [w:] Polski słownik biograficzny, t. XXVI, Kraków 1981, s. 693-694.

${ }^{4}$ M.H. Mazurek, Powstanie i rozwój ukrytych zgromadzeń bł. Honorata Koźmińskiego w latach 1874-1908, Sandomierz 2009. 
dwutygodnikiem o charakterze literacko-społecznym i pamiętnikarsko-podróżniczym, który wiele uwagi poświęcał tzw. kwestii kobiecej $^{5}$. W 1873 r. „Kronika Rodzinna” znalazła się w gestii działaczy dawnego Towarzystwa Rolniczego - Adama Goltza i Ludwika Górskiego. W polemikach $z$ młoda prasa pozytywistów pismo nabierało religijnego rozpędu ${ }^{6}$. Wskazując na ognisko rodzinne jako ostoję tradycji z ideałem rodziny ziemiańskiej, kobietę widziano w roli jego opiekunki i działaczki społeczno-gospodarczej. Po wyciszeniu ideologicznych sporów, od 1880 r. redakcja z sympatiami oświeconego konserwatyzmu pielęgnowała zainteresowania literackie. Skupiała też uwage na sprawach domowych i wychowawczych, płynąc $z$ umiarkowanym nurtem ruchu równouprawnienia kobiet, propagowała ich zawodowe wykształcenie oraz aktywność. Ta optyka programowa zachowała się również po roku 1896, kiedy „Kronikę Rodzinna” przejmował ks. Marceli Godlewski. Zwolennik doktryny katolicyzmu społecznego kierował periodyk w stronę chrześcijańskiej demokracji. W styczniu 1899 r., wobec problemów z cenzura, funkcję jego naczelnej redaktorki i wydawczyni powierzył współpracującej z pismem Plater-Zyberkównie, która w swoich poglądach asymilowała ziemiańskie, zachowawcze ideały $z$ inteligenckim modelem otwartego katolicyzmu. W okresie jej prawie rocznej kadencji następowało przesilenie w rozwoju „Kroniki Rodzinnej”, przekształcanej w popularne, wyrażone w podtytule „Czasopismo dla Rodzin Katolickich". Przyjmując funkcję jego naczelnej, wchodziła do niezbyt licznej grupy kobiet $z$ kręgu mediów, które przebijały się przez niechęć opinii publicznej i obok mężczyzn zdobywały status profesjonalnych publicystek, pisarek i niekiedy również dziennikarek ${ }^{7}$.

Znamienne, że Plater-Zyberkówna swój awans w redakcji „Kroniki Rodzinnej” zainaugurowała i zamknęła drukowanym w odcinkach reportażem podróżniczym. Sprawozdawczy, celowy charakter wyjazdu podkreślała $z$ odwołaniem do idei, że „Podróże $z$ myślą podjęte bywają zawsze znakomitym przyczynkiem postępu”. Ary-

${ }^{5}$ M. Sikorska-Kow als ka, Kwestia kobieca $w$ świetle programu społecznego „Kroniki Rodzinnej” Aleksandry Borkowskiej (1867-1872), „Acta Universitatis Lodziensis", Folia Historica 61, 1998, s. 17-32.

${ }^{6}$ B. Le sis $z$, Polskie czasopisma religijno-społeczne $w$ XIX w., Warszawa 1988, s. 305-306.

7 Por. Kobieta i media. Studia $z$ dziejów emancypacji kobiet, red. P. Perkowski, T. Stegner, Gdańsk 2009.

8 Wrażenia $z$ wycieczki gospodarczej po ks. Poznańskiem, Niemczech, Francji, Czechach. Cel podróży - Dobrojewo - Borejowice [właśc. Bożejowice], „Kronika Rodzinna" [dalej: KR] 1899, nr 1, s. 15. 
stokratka wyrosła w rodowej tradycji północnych, kurlandzkich kresów o wieloetnicznej i zróżnicowanej religijnie kulturze, postęp ten utożsamiała $z$ najbardziej pilna potrzebą podnoszenia religijnych, społecznych, gospodarczych standardów życia Polaków $\mathrm{w}$ nowoczesnej, płynacej $z$ Zachodu cywilizacji. A znała ja nieźle $z$ racji przynależności do elity, która wojaże po świecie miała zakorzenione w środowiskowej specyfice ${ }^{9}$. Podróżnicze pasje towarzyszyły hrabiance od wczesnej młodości, kiedy razem $z$ rodzina przemierzała Europę oraz wszystkie zaborowe dzielnice, w których znajdowały się siedziby i majątki silnie rozgałęzionego rodu Plater-Zyberków. Zdobywaną wówczas wiedzę oraz obserwacje cywilizacyjnych dystansów wykorzystywała w działalności oświatowej, tworząc w 1891 r. w Chyliczkach pod Warszawą, żeńską Szkołę Gospodarstwa Wiejskiego ${ }^{10}$.

W towarzystwie przełożonej tej placówki przyszła naczelna „Kroniki Rodzinnej” 17 lipca 1898 r. wyruszyła z Chyliczek w ponad trzytygodniowa podróż po Europie Środkowej i Zachodniej, przez Wielkie Księstwo Poznańskie, Niemcy, Francję i Czechy ${ }^{11}$. Kobiety, które wyruszyły $\mathrm{w}$ tę samodzielna wędrówkę, łączyła wieloletnia przyjaźń, wyrosła na gruncie współpracy w organizowaniu i prowadzeniu szkoły. Panna Felicja, tylko imiennie przywoływana w prasowej opowieści, odpowiadała za gospodarczy charakter funkcjonowania szkoły ${ }^{12}$. Wychowanie i sprawy religii pozostawały w gestii Plater-Zyberkówny, pełniącej też funkcję mentorki w wyprawie na europejskie szlaki. Nadrzędna myśla wejścia na nie, poza ogólna idea śledzenia postępu, było poszukiwanie szkół gospodarczych dla dziewcząt.

Wykształcenie zawodowe kobiet związane $z$ ich aktywizacja na rynkach pracy, szczególnie od drugiej połowy XIX w., było problemem zapalnym i cywilizacyjnym wyzwaniem epoki. W końcu

${ }^{9}$ Por. Ziemiaństwo na Lubelszczyźnie IV. Ziemianie $w$ podróży, t. I-II, red. H. Łaszkiewicz, Lublin 2010.

${ }^{10}$ E.M. Kostrzewska, Szkolnictwo gospodarczo-rolnicze ziemianek Królestwa Polskiego na przełomie XIX i XX w. Między tradycja a nowoczesnościa, [w:] Z dziejów polskiej kultury i oświaty od średniowiecza do poczatków XX wieku, red. K. Jakubiak, T. Maliszewski, Kraków 2010, s. 152 i n.

${ }_{11}$ Wrażenia z wycieczki gospodarczej po ks. Poznańskiem..., s. 15-18.

12 Wspólnie z Plater-Zyberkówną podróżowała Felicja Czyż, podobnie jak hrabianka należąca do bezhabitowego zgromadzenia sióstr posłanniczek. Jej zaangażowaniu w prace gospodarcze szkoły wiele uwagi poświęcała w swoich wspomnieniach przełożona zgromadzenia, Józefa Chudzyńska. Archiwum Posłanniczek w Konstancinie-Jeziornie, bez sygn.; J. Chudzyńs ka, Pamiętnik, s. 207-211. 
stulecia coraz lepiej wykształcone coraz wyższa falą napływały do nowych zawodów, rezerwowanych dotąd dla mężczyzn ${ }^{13}$. Włączały się do nich również kobiety związane $z$ rolnictwem, którym nowoczesne myślenie o zajęciach gospodyni domowej i pracy na wsi wpoić miały szkoły gospodarcze. Plan wyjazdu Plater-Zyberkówny zakładał zdiagnozowanie ich sytuacji oraz porównanie tego typu zagranicznych placówek z Chyliczkami. Swój reportaż podróżniczka rozpoczęła relacja $z$ tygodniowego pobytu w Wielkim Księstwie Poznańskim.

Rolnictwo tej dzielnicy zaborowej było synonimem nowoczesności i postępu cywilizacyjnego. Ziemianie wielkopolscy $z$ waską warstwa arystokracji należeli do najlepiej przygotowanych do zawodu rolnika i najbardziej zbliżonych do wielkich właścicieli ziemskich z krajów Europy Zachodniej. Dążąc do zachowania w polskim społeczeństwie pozycji hegemona i skutecznego rywalizowania o ziemię z żywiołem niemieckim, modernizowali majatki i adaptowali styl życia uspołecznionych "gentleman farmerów” ${ }^{14}$. W prace gospodarcze i społeczne angażowały się także kobiety, w tym arystokratki ${ }^{15}$. Słynna we wszystkich trzech zaborach $z$ prowadzenia w Dobrojewie szkoły gospodarczej dla córek chłopskich była Barbara z Mańkowskich Kwilecka ${ }^{16}$. Jej majątek był pierwszym punktem na trasie gospodarczej podróży Plater-Zyberkówny. Mieszkając w należącym do właścicielki pałacu, była ona częścią świata jego mieszkańców, a jednocześnie przybywała $z$ zewnattrz i z takiej podwójnej perspektywy opisywała sytuację zwiedzanej szkoły i swoje wrażenia. Jej entuzjazm wzbudzało wychowywanie dziewcząt $z$ ludu w duchu katolickiego solidaryzmu społecznego powiązanego $z$ wyposażaniem w podstawy wiedzy: czytania, pisania, rachunków. Podziwiała tryb ich przysposobienia do zawodowych obowiązków służby domowej i dworskiej, nadawanie dziewczętom stopnia elewek, ujednoli-

${ }^{13}$ Z. Chyra-Rolicz, Pionierki $w$ nowych zawodach na początku XX wieku, [w:] Kobieta i edukacja na ziemiach polskich $w$ XIX $i$ XX w. Zbiór studiów, t. II, cz. 2, red. A. Żarnowska, A. Szwarc, Warszawa 1992, s. 221-236.

${ }^{14} \mathrm{~W}$. Molik, Przekształcanie sie wielkopolskiego szlachcica $w$ ziemianina - uspołecznionego farmera w XIX i na poczatku XX w., [w:] Ziemiaństwo wielkopolskie. W kręgu arystokracji, red. A. Kwilecki, Poznań 2004, s. 24-26.

15 I d e m, Ziemianki wielkopolskie $w$ codziennych zajęciach gospodarczych $i w$ pracy społecznej $w$ drugiej połowie XIX $i$ na poczatku XX wieku, [w:] Kobieta i kultura życia codziennego wiek XIX i XX. Zbiór studiów, t. V, red. A. Żarnowska, A. Szwarc, Warszawa 1997, s. 181-190.

${ }^{16}$ D. Kamiński, Barbara z Mańkowskich Kwilecka-wybitna Wielkopolanka, „Wiadomości Ziemiańskie” 2017, nr 71, s. 82-88. 
cenie ich stroju. Białe czepki i fartuchy symbolizować miały prestiż wychowanek hrabiny, a jednocześnie zapewnić podwójną ochronę: przed nagabywaniem ze strony mężczyzn zatrudnionych w pałacu oraz nadmiernymi aspiracjami społecznymi. Umundurowanie elewek służyło więc zapewnieniu ich autoidentyfikacji z płatną służbą. Pod kierunkiem służących w wyższej randze dziewczęta odbywały trzyletnie praktyki w kuchni, spiżarni, pralni, gospodarstwie podwórzowym. Tym samym, zdaniem Plater-Zyberkówny, nauczanie gospodarstwa wiejskiego w Dobrojewie, godne popularyzowania, odbiegało jednak od standardu prawdziwej szkoły.

Autorka przyglądała się też kondycji dóbr w Dobrojewie i w pobliskim Oporowie. Opisując $z$ reporterską dokładnością folwarczne zabudowania, nie skrywała fascynacji "męskim gospodarstwem”. Nie ukrywała też „pożądañ”, chęci posiadania w Chyliczkach równie pięknych okazów trzody czy rasowego bydła. Jak pisała: „każda krowa, codziennie myta i czyszczona zgrzebłem lśniła się jak jaki wierzchowiec"17.

W innym kontekście, nawiązującym do żywotnych dla ziemiaństwa i znanych $z$ Dobrojewa problemów $z$ zatrudnianiem wykwalifikowanej służby czy urzędników gospodarczych, opisywała wzorowa hodowlę drobiu prowadzoną w Bożejewicach przez Helenę Potworowska ${ }^{18}$. Nowoczesność i otwartość właścicielki kurzej fermy, niestroniącej od zagranicznych nowinek technicznych, mogła być przykładem dla kobiet $z$ arystokratyczno-ziemiańskich środowisk, które wchodziły w obszar gospodarczych sukcesów $z$ najbardziej dochodowymi działami: drobiarstwa i mleczarstwa ${ }^{19}$. Podróżniczka postanowiła też sprawdzić, czy prawdziwa jest potoczna opinia o dużym wpływie niemieckich szkół na profesjonalizację pracy kobiet $\mathrm{w}$ wiejskim gospodarstwie. Nieudane próby uzyskania od wielkopolskich arystokratek informacji na ten temat Plater-Zyberkówna podsumowała słowami: „Cicho wszędzie, głucho wszędzie. Co to będzie! Co to będzie"20. Zdeterminowana, uparta tropicielka nowoczesności postanowiła rozwikłać tę zagadkę.

17 Wrażenia z wycieczki gospodarczej po ks. Poznańskiem, Niemczech, Francji, Czechach. Dalszy ciag, KR 1899, nr 2, s. 46.

${ }_{18}$ Ibidem, s. 47-48.

19 E.M. Kostrzewska, Ziemianki Królestwa Polskiego a gospodarka. Koncepcje $i$ empiria (przełom wieków XIX i XX), „Studia Maritima” [Szczecin] 2015, t. XXVIII, red. Z. Anusik, R. Gaziński, s. 295-315.

${ }^{20}$ Wrażenia $z$ wycieczki gospodarczej..., s. 46. 
Pierwszym krokiem było dotarcie do polskiej szkoły w Śremie ${ }^{21}$. Informacje na ten temat uzyskała wcześniej w Warszawie, co pozwoliło jej wprowadzić tę szkołę do podróżniczej „kolekcji obrazków gospodarczych" 22 . Krótka droga do Śremu była udręką. Pociag poruszał się $z$ prędkościa rodząca pokusę pokrzykiwania, jak na „kulawą szkapinę: A nuże, wiu, wiu, wiu!!!”23. Sama placówka okazała się rozczarowaniem. Założona i prowadzona przez Felicjannę Szczerbińska, okazała się zakładem wychowawczym $z$ rocznym kursem gospodarstwa domowego. Renomę szkoły ratował dobry poziom zajęć praktycznych, wychowanie religijne i patriotyczne, dbałość o higienę pracy i zdrowie uczennic. Mankamentem była rezygnacja $z$ prowadzenia działu gospodarstwa wiejskiego, wymuszona brakiem środków finansowych oraz zainteresowania uczennic. Plater-Zyberkówna kwestię tę widziała przez pryzmat specyfiki zaboru pruskiego, gdzie szczególną wage przywiązywano do kształcenia dziewcząt dającego im wiedzę ogólną. Zauważała także kapitalistyczne przemiany w wielkopolskim rolnictwie, do których kobiety nie potrafiły dostosować własnych aspiracji i przedsiębiorczości. Nauczanie gospodarstwa domowego ograniczało się w Śremie do umiejętności zaspokajania potrzeb rodziny. Nie dawało zawodowego statusu i przygotowania do obejmowania płatnych posad. Na zdecydowanie wyższym poziomie stały rządowe szkoły niemieckie w Poznaniu. Świetnie wyposażone, były już szkołami na miarę XX wieku.

Kolejnym etapem podróży Plater-Zyberkówny był Berlin. „Dnia 23 lipca rozpoczęłyśmy na dobre nasza wycieczkę gospodarcza. Z Poznania wyruszyłyśmy o 4-ej po południu do Berlina [...]. Berlin znałam dobrze, zwiedzałam go niejednokrotnie, obecnie nie przedstawiał dla mnie żadnej atrakcji” - pisała podróżniczka ${ }^{24}$. Ze stolicy Niemiec nasza podróżniczka ruszyła prosto do Hanoweru, pomijając Hamburg, słynacy $z$ nowoczesnych ferm hodowli drobiu. Polecony jej hotel okazał się „Dużą budą trochę odświeżona”" 25 . $Z$ najwyższym trudem podróżujące samodzielnie Polki zdobyły adres znanej w mieście fermy drobiarskiej. Po dość długo trwającej podróży

${ }^{21}$ Dzieje Śremu, red. S. Chmielewski, Warszawa-Poznań 1972, s. 226-227.

22 Wrażenia z wycieczki gospodarczej po ks. Poznańskiem, Niemczech, Francji, Czechach. Dalszy ciag, KR 1899, nr 3, s. 83.

${ }^{23}$ Ibidem.

${ }^{24}$ Wrażenia z wycieczki gospodarczej po ks. Poznańskiem, Niemczech, Francji, Czechach przez C.P.Z. Dalszy ciag. Hanower. Hodowla drobiu, mleczarnia, KR 1899, nr 5 , s. $147-148$.

${ }^{25}$ Ibidem, s. 148. 
Plater-Zyberkówna dotarła wreszcie do interesujących ją kurników. Rozmowę $z$ właścicielem zakończył zakup rasowych kur i kogutów przeznaczonych dla fermy w Chyliczkach. Udana transakcja przeprowadzona już w Hanowerze pociagnęła za soba rezygnację $z$ planów podróży do Francji. Po dokonanym tu zakupie rasowego drobiu i zwiedzeniu nowoczesnej mleczarni Hanower nie miał już nic więcej do zaoferowania polskim podróżniczkom. Szybko więc wyznaczyły sobie nowy punkt wyprawy, którym była szkoła gospodarczo-rolnicza dla dziewcząt w osadzie Alzay pod Moguncją ${ }^{26}$.

Wbrew oczekiwaniom tamtejszy zakład okazał się standardowa szkoła gospodarstwa domowego. Zbliżony modelem edukacji do szkoły w Śremie, odróżniał się od niej niewielką liczbą, zaledwie 20 dziewcząt i dobra kondycją finansowa, zapewniana przez państwo, samorządy oraz wpłaty uczennic. W porównaniu $z$ Chyliczkami, przedstawionymi w opowieści Plater-Zyberkówny jako nowoczesny, samofinansujaccy się kombinat gospodarstwa wiejskiego, szkoła w Alzey wypadała jednak blado.

Mimo imponujacej siedziby, ulokowanej w obszernej kamienicy, wodotrysków, doskonale skanalizowanych mleczarni i serowni wyłożonych glazura, godnego pozazdroszczenia wyposażenia kuchni, zajęcia dziewcząt w ciagu pięciu miesięcy nauki ograniczały się do gotowania, szycia, prania, wyrabiania sera i masła oraz sporzadzania konfitur. Niewątpliwą zaletą tej placówki było też nauczanie zasad rachunkowości, co mogło pomóc wychowankom w planowaniu budżetu domowego. Dominowały tu jednak zajęcia praktyczne, których prozaiczność w odczuciu Plater-Zyberkówny pogłębiała chłodna atmosfera surowego protestantyzmu, powodująca, że „wszystko tu obraca się jedynie na ziemi, i dla ziemi” ${ }^{27}$. Protestantyzm uczył chrześcijańskiej moralności, ale deprecjonował uczucia.

Dominującym rysem stylu życia i pracy dziewcząt była mieszczańskość. Uczennice sprawiały niemiłe wrażenie. Na ciężkich sylwetkach dziewcząt $z$ ludu suknie mieszczańskie „z opadającymi ogonkami i falbankami”, nieosłonięte fartuchami wyglądały pretensjonalnie. Były niehigieniczne i tandetne. Groteskowość wyostrzało porównanie $z$ granatowymi, płóciennymi, szkolnymi mundurkami i białymi, roboczymi fartuchami uczennic w Chyliczkach.

${ }^{26}$ Wrażenia z wycieczki gospodarczej po ks. Poznańskiem, Niemczech, Francji, Czechach przez C.P.Z. Szkoła gospodarcza w Alzay pod Moguncja, KR 1899, nr 7, s. 227.

${ }^{27}$ Wrażenia $z$ wycieczki gospodarczej po ks. Poznańskiem, Niemczech, Francji, Czechach przez C.P.Z. (Dalszy ciag), KR 1899, nr 8, s. 256. 
Niemiecka mieszczańska cywilizacja odpowiadała też za wygląd części mieszkalnej szkoły, szczególnie sypialni uczennic $z$ „czerwonymi puchówkami” na łóżkach. Ten motyw polska arystokratka eksponowała w całej swojej opowieści z podróży. Szkoła w Alzay była na jej trasie punktem kluczowym. $Z$ relacjonowanych $w$ reportażu rozmów $z$ dyrektorem i całą szkolną społecznością wynikało, że w Nadrenii wśród wielu podobnych placówek szkoła ta uchodziła „za gwiazdę i wzór”28. Uczennice szkoły w Alzay pożegnały polskie podróżniczki odśpiewaniem kantaty $O$, Du theures Vaterland (O miłości ojczyzny), co było akordem symbolicznym.

Kolejne etapy podróży były dla autorki reportażu okazją do komentarzy o świecie industrialno-miejskiej, zachodniej cywilizacji. Jej ekspansja, w oczach Plater-Zyberkówny, burzyła krajobraz uważany za wiejski. Domy i kamienice zagarniały tę przestrzeń, stanowiły część miasta przeniesiona poza jego obręb. Ten zlewajacy się krajobraz zacierał społeczne dystanse, co kłócić się miało z przyrodzonym porządkiem rzeczy. Ludowi należały się sprawiedliwość, prawo do oświaty i pracy $-z$ zachowaniem jednak hierarchii i harmonii społecznej, chrześcijańskich obyczajów oraz wiejskiej prostoty życia, co wpajać powinny wychowanie i edukacja. Nie było to jednak zadanie łatwe, o czym świadczyć miały przywoływane przez Plater-Zyberkównę aspiracje niektórych uczennic Chyliczek do miejskiego stylu życia. Jak pisała, gotowe były wkładać kapelusze i „tiul na gębę"29.

Rodziło to pytanie, czy można znaleźć szkołę, która dając wiedzę i zawód, pozwoliłaby wyrobić w uczennicach poszanowanie dla ładu społecznego i przywiąanie do wiejskiego stylu życia. Taka nadzieja pojawiła się w Moguncji, gdzie polskie podróżniczki trafiły do szkół prowadzonych przez żeńskie zgromadzenia zakonne, które w Niemczech przeżywały swoisty renesans. Największy aplauz poszukiwaczki idealnej szkoły wzbudził zakład „Haus haltung schule", kształcący dziewczęta $z$ dobrych rodzin ${ }^{30}$. Opisując tę placówkę, Plater-Zyberkówna podkreślała jej oryginalność. W kom-

\footnotetext{
28 Ibidem.

${ }^{29}$ Ibidem, s. 259.

${ }^{30}$ Wrażenia $z$ wycieczki gospodarczej po ks. Poznańskiem, Niemczech, Francji, Czechach przez C.P.Z. (Dalszy ciag). Moguncja, KR 1899, nr 9, s. 289-291; Wrażenia z wycieczki gospodarczej po ks. Poznańskiem, Niemczech, Francji, Czechach przez C.P.Z. (Dalszy ciag), KR 1899, nr 10, s. 328-331. We współczesnym tłumaczeniu znaczyło to: Szkoła sprzątania i żywienia, w Niemczech szkoły tego typu istnieją do dziś.
} 
pleksie budynków zajmowanych przez klasztor i szkołę parter przeznaczony był na pensjonat $z$ apartamentami dla zamożnych turystek. W ten sposób w podmiejskiej dzielnicy ogrodów stworzony został elitarny, wyemancypowany świat kobiet, niedostępny dla mężczyzn.

Pensjonat, obsługiwany przez uczennice, zdaniem Plater-Zyberkówny, mógł zapewnić staż dziewczętom przygotowującym się do służby. Ale szkoła nie stawiała sobie takich zadań. Jej celem było katolickie wychowanie i kształcenie w zakresie nowoczesnego prowadzenia gospodarstwa domowego, bez zawodowych certyfikatów. Program realizowano w komfortowych warunkach pięciu pomieszczeń kuchennych, przestronnych sal wykładowych, jadalni i sypialni uczennic. Wyposażony w centralne ogrzewanie, łazienki, garderoby, pralnie, zakład imponował estetyką i porządkiem. Przestępując progi szkoły, podróżniczki poczuły się w swojskim miejscu, „gdzie wszystko tchnęło miłością Boga i ludzi”"31. Według Plater-Zyberkówny wartości te powinna podzielać cała cywilizowana Europa. Siostry zakonne łączyły afirmację religii $z$ pragmatyzmem pracy i talentami menedżerek. $Z$ tych walorów skorzystały polskie podróżniczki i szybko przeniosły się $z$ hotelu do przyszkolnego pensjonatu, nie ukrywając zamiarów jego rozreklamowania. Kilka szpalt druku poświęconych opisowi wnętrz i zalet szkoły oraz pensjonatu to jednocześnie opowieść o europejskich ekskluzywnych kuchniach hotelowych, niedorównujących jakością luksusowemu wyżywieniu serwowanemu w zakładzie w Moguncji ${ }^{32}$. Przy tej okazji założycielka Chyliczek nie omieszkała zareklamować sklepu ze zdrowa żywnościa, prowadzonego przy tym zakładzie ${ }^{33}$.

Ostra krytyka miejskiej mleczarni $z$ powodu jej antyhigienicznych warunków oraz zakupy w magazynie mód zamykały pobyt w Moguncji. Zbliżało się też zakończenie niemieckiego etapu podró$\dot{z} y$, gdyż dalszy plan przewidywał przejazd przez Frankfurt i Lipsk do Pragi. W czasie przejazdu do stolicy Czech Plater-Zyberkówna snuła rozważania o przesłaniu zawartym w encyklice Rerum novarum, gdzie obok wyraźnej krytyki wyzysku kapitalistycznego pojawiły się idee tzw. społecznego katolicyzmu. Swoje refleksje na ten temat autorka reportażu zamknęła konkluzją: „Łatwo mi zapewne, $z$ daleka, wygodnie w wagonie jadąc, rozwiązywać zawiłe zagadnie-

\footnotetext{
${ }^{31}$ Wrażenia z wycieczki gospodarczej..., nr 10, s. 329.

${ }^{32}$ Wrażenia z wycieczki gospodarczej..., nr 9, s. 290.

33 Wrażenia z wycieczki gospodarczej..., nr 10, s. 330.
} 
nia społeczne, nad którymi biegli ekonomiści susza sobie głowy"34. Hrabianka opowiadała się za chrześcijańsko-społeczną zasadą: sprawiedliwej płacy za uczciwą pracę.

Ponieważ w okolicach Frankfurtu i Lipska polskie podróżniczki nie znalazły nic godnego uwagi, pięciogodzinny czas oczekiwania na pociag do Pragi Plater-Zyberkówna wypełniła wspomnieniami ze swoich wcześniejszych podróży do Paryża i Linzu. Pierwsza retrospekcja dotyczyła krótkiego wyjazdu wiosna 1894 r. do położonej w pobliżu stolicy Francji, jedynej wówczas rządowej szkoły hodowli drobiu ${ }^{35}$. „Biorac pociąg najśpieszniejszy i jadąc bez wytchnienia”, autorka reportażu dotarła do Paryża, skąd dalsza droga do Gambais Houdan upłynęła jej w towarzystwie Jadwigi hr. Zamoyskiej, twórczyni ideowo bliskiej Chyliczkom szkoły gospodarstwa domowego założonej w 1882 r. w Kórniku i przeniesionej z powodu pruskich represji do Kuźnic koło Zakopanego ${ }^{36}$. Celem podróży było odkrycie przyczyn awarii inkubatora, kupionego wcześniej w podparyskiej szkole. Uznany za osiagnięcie cywilizacji, niszczył hodowlę drobiu w Chyliczkach. Dociekliwe arystokratki odkryły, że przyczyną był świadomie ukrywany błąd techniczny urządzenia. $Z$ rezerwą więc przyglądały się podparyskiej szkole. Brak higieny, staranności i humanitaryzmu w traktowaniu ptaków - to były jej grzechy główne. Pokoje gościnne przerobione $z$ kurników, fatalne wyżywienie, arogancja dyrekcji, niesubordynowana służba dopełniały obrazu całości. Poważnym mankamentem tej placówki był również jej koedukacyjny charakter, co mogło stanowić, zdaniem polskich arystokratek, zagrożenie dla zasad moralności. Kolejnym etapem podróży była miejscowość Mantes, gdzie mieścił się zakład hodowli drobiu oraz produkcji inkubatorów. Nabyty tam inkubator wraz $z$ okazami rasowego drobiu został zabrany do Polski. Po powrocie do Chyliczek wadliwy, stary inkubator został spalony, a jego zadania $z$ sukcesem spełniało odtąd nowe urzadzenie nabyte w specjalistycznym zakładzie.

Propagowanie kultury technicznej było jednym $z$ głównych zadań szkół gospodarczych i celem relacjonowanej tu podróży. W swoją opowieść retrospekcyjną wprowadziła więc autorka sprawozdanie

${ }^{34}$ Wrażenia $z$ wycieczki gospodarczej po ks. Poznańskiem, Niemczech, Francji, Czechach przez C.P.Z. (Dalszy ciag), KR 1899, nr 11, s. 365.

35 Paryż i jego okolice (Z wycieczki gospodarczej) przez C.P.Z., KR 1899, nr 13, s. $435-440$.

${ }^{36}$ K. Czachowska, Generałowa Jadwiga Zamoyska (1831-1923). Życie i dzieło, Poznań 2011, s. 233 i n. 
z dokonań kolejnej szkoły, zwiedzonej przez nią w grudniu 1895 r. ${ }^{37}$ Trasą przez Wiedeń i Linz dotarła wówczas do miejscowości Mittelsbach. Położona w górach Tyrolu, wyróżniała się posiadaniem założonego w 1889 r. zakładu gospodarczego dla dziewcząt, prowadzonego przez zakonnice ze zgromadzenia franciszkanek. Szkoła, podlegająca nadzorowi władz państwowych, nie wzbudziła entuzjazmu Plater-Zyberkówny. Jak w większości opisywanych szkół, nacisk kładziono tu bowiem na prace domowe. Folwarkiem zarządzała osobna gospodyni. Była nią: „Kobieta potężna, jak piec kurlandzki, która by dwóm chłopom poradziła"38, ale która nie przykładała się zbytnio do swoich nauczycielskich obowiąków. Dziewczęta wychowywane były w duchu niemieckiego porządku, ustawicznie czyściły i sprzątały nieźle technicznie wyposażone pomieszczenia mieszkalne i gospodarcze. Szkolę pozytywnie wyróżniała atmosfera głębokiej religijności i wpajanego uczennicom duchowego skupienia, co wyraźnie kontrastowało $z$ opisywanym wcześniej krzykiem i przepychankami koedukacyjnego grona podopiecznych szkoły francuskiej. Swoje doświadczenia $z$ wcześniejszych wyjazdów określiła autorka jako: „prawdziwe steeple-chasse $z$ przeszkodami””.

Kraj, do którego przybywała, czyli pozostające pod władzą Habsburgów Czechy, charakteryzował wprowadzany tu w życie organicznikowski model postępu w rolnictwie, który budził żywe zainteresowanie wielkopolskich społeczników, także ze względu na podobieństwa $\mathrm{w}$ walce $z$ niemczyzną. Plater-Zyberkówna stwierdzała, że pobyt w Czechach stanowił kulminacyjny punkt jej wyprawy i odwoływała się przy tej okazji do powszechnej opinii o wyjątkowym wkładzie kobiet w rozwój czeskiej cywilizacji ${ }^{40}$. Docelowym punktem podróży była Praga, skąd wraz z panną Felicją zamierzała „jeździć w prawo i w lewo"41.

Pierwsze wrażenia nie były zbyt korzystne. Czysty damski przedział w niemieckim pociagu został zamieniony na czeski wagon, co oznaczało podróż w tytoniowym dymie i w marnym towarzystwie. Hotel „Royal” tradycyjnie okazał się „stara budą”. Jednocześnie jednak wędrówki po Czechach przestawały być, jak dotychczas,

${ }^{37} \mathrm{Na}$ stoku gór tyrolskich. Obronny zameczek pod Linzem. (Z wycieczki gospodarczej) napisała C.P.Z., KR 1899, nr 16, s. 533.

${ }^{38} \mathrm{Na}$ stoku gór tyrolskich. Obronny zameczek pod Linzem. (Z wycieczki gospodarczej) napisała C.P.Z. (Dokończenie), KR 1899, nr 17, s. 558.

${ }^{39}$ Ibidem, s. 560.

40 Tydzień spędzony w Czechach. Napisała C.P.Z., KR 1899, nr 19, s. 630.

${ }^{41}$ Ibidem, s. 632. 
wyprawami w nieznane. Były to bowiem starannie zaplanowane wyjazdy do szkół, których rejestr dostarczyło obu Polkom profesjonalne biuro informacji dla rolników i gospodarzy. Zwiedzane tu mleczarnie, zlokalizowane na przedmieściach Pragi, nie odbiegały od technologicznych wymogów zachodniej cywilizacji. Propagatorka kształcenia w zakresie mleczarstwa była w Czechach pani Pich-Polakowa, rekomendowana przez biuro informacji nauczycielka i autorka cenionego podręcznika. Wprowadzała ona polskie podróżniczki w świat czeskich szkół gospodarskich i miejscowych kobiet. Te ostatnie stały się ważnymi bohaterkami reportażu Plater-Zyberkówny, która podkreślała ich zasługi w dziele rozbudzania narodowych aspiracji w czeskim społeczeństwie.

W czasie pobytu w Czechach Plater-Zyberkówna odwiedziła zakłady dla dziewcząt prowadzone w miasteczkach Stěžery i Louny ${ }^{42}$. Pierwszy $z$ nich mieścił się w świeżo wybudowanym, imponującym gmachu, który standardem i programem nauczania nie odbiegał od opisywanych wcześniej szkół niemieckich. Różnił się od nich zwróceniem nieco większej uwagi na wiejskie gospodarstwo. Mniej komfortowo wyposażona była szkoła w Louny, ale w swoim wystroju miała więcej czeskich akcentów, a także bardziej rozbudowany dział wiejskiego gospodarstwa. Zakłady te, jak większość poprzednich, miały status szkół rządowych i nie były zobowiazane do wystawiania certyfikatów upoważniających do podjęcia pracy zawodowej, czego oczekiwano od prywatnej szkoły w Chyliczkach. Problem ten pojawiał się wielokrotnie w opowieściach Plater-Zyberkówny, która marzyła o przekształceniu Chyliczek w pierwszą wyższą szkołę rolnicza dla kobiet. Projekt ten w końcu wieku XIX nie miał jednak szans realizacji.

Plater-Zyberkówna swój wolny czas poświęcała na zwiedzanie Pragi. Spisała też wrażenia ze zwiedzanej przez siebie wystawy osiągnięć $\mathrm{w}$ zakresie architektury oraz aranżacji wnętrz. Ostro skrytykowała przedstawicielki praskich sfer wyższych. Kobietom, mimo dostępu do luksusowych magazynów mód, brakować miało szyku, wdzięku i urody. Nie podobał się jej też religijny indyferentyzm czeskich elit.

Przywiazanie do religii zachowali natomiast chłopi, do których z misją cywilizacyjna docierały czeskie emancypantki. Walczyły one o prawa kobiet do wykształcenia, pracy zawodowej i prestiżu.

${ }^{42}$ Tydzień spędzony $w$ Czechach napisała C.P.Z. (Dalszy ciag), KR 1899, nr 20, s. 661 . 
Katalog bohaterek reportażu Plater-Zyberkówny tworzyły kobiety powszechnie wówczas znane ${ }^{43}$. Prezentację otwierały prekursorki emancypacji, pisarki i społeczniczki, Helena Nemcowa (18201862), Karolina Světlá (1830-1899), Honorata Zapová (1825-1856) oraz Eliška Krásnohorská (1847-1926), redaktorka wydawanego od roku 1891 kobiecego pisma „Ženské listy”44. Obok nich wystąpił również związany $z$ ruchem emancypacji kobiet działacz oświatowy, Vojta Náprstek (1826-1894), który w 1848 r. zbiegł przed represjami do Stanów Zjednoczonych, a po powrocie założył Amerykański Klub Dam ${ }^{45}$. Z kręgu wspomnianych tu działaczy społecznych wyszły pierwsze inicjatywy organizowania wiejskiej oświaty i szkół ludowych. W tym właśnie nurcie mieściły się polecone polskim podróżniczkom przez Pich-Polakową cztery zakłady gospodarcze kształcące dzieci chłopskie. Pierwsze dwa stanowiły szkoły dla dziewcząt i chłopców założone w osadzie Kremsir (Kromieryż). Były one prowadzone przez małżeństwo - żona zajmowała się szkoła żeńską $z$ internatem, a mąż odpowiadał za kształcenie chłopców $z$ okolicznych wsi. Ten pomysł wychowania i edukacji - we własnym, społecznym i rodzinnym środowisku - Plater-Zyberkówna oceniała jako najbardziej właściwy dla cywilizowania ludu. Próby wyemancypowania ludu $z$ jego środowiska krytykowała $z$ zapamiętaniem, oczekując od polskiego ziemiaństwa zainteresowania czeskim modelem funkcjonowania wiejskich szkół gospodarczych.

Za wzór godny naśladowania uznała odwiedzone przez siebie na terenie Moraw szkoły: męską i żeńska, założone we wsi Sohle ${ }^{46}$. Usytuowane w pobliżu siebie, były jedynymi spośród placówek opisanych $\mathrm{w}$ reporterskiej opowieści, zakładami zlokalizowanymi na wsi. Budynek żeńskiej szkoły otaczały zieleń, duży ogród warzywny i zabudowania gospodarcze, gdzie rasowe krowy trzymane były w oborze, „istnym cacku $z$ wykwintnym porzadkiem”. W programie nauczania proporcjonalnie łączono działy gospodarstwa domowego i wiejskiego. Mleczarnię prowadziła nauczycielka - profesjonalistka,

43 Por. P. Vošahlik ková, Pozycja społeczna i prestiż kobiety pracujacej zawodowo w Czechach na przełomie XIX i XX wieku, [w:] Kobieta i praca. Wiek XIX i XX. Zbiór studiów, t. VI, red. A. Żarnowska, A. Szwarc, Warszawa 2000, s. 255-266.

${ }^{44}$ Tydzień spędzony $w$ Czechach napisała C.P.Z. (Dalszy ciag), KR 1899, nr 22, s. $725-729$.

45 Ibidem, s. 728-729.

46 Tydzień spędzony w Czechach napisała C.P.Z. (Dokończenie), KR 1899, nr 24, s. 790-791. 
w stroju i o wyglądzie „bardzo dobrze wychowanej osoby”47. Równie znakomicie, $z$ „kokieteria porzadku”, prowadzona była szkoła męska. Według Plater-Zyberkówny wzajemnie się uzupełniające szkoły gospodarcze we wsi Sohle stanowiły najlepszy przykład emancypacji kobiet i nowoczesnej cywilizacji.

Kończąc prezentację reportażu autorstwa założycielki szkoły w Chyliczkach, warto zwrócić uwagę na jej przemyślenia o bardziej ogólnym charakterze. Otóż uważała ona, że dążenie kobiet do równouprawnienia, rozbudzane przez przedstawicieli liberalnego pozytywizmu, kontestujących religię, prowadziły kobiety na manowce życia w świecie zaburzonych wartości i ładu społecznego. Powrót na wieś, do korzeni cywilizacji oznaczał przywrócenie przyrodzonego człowiekowi porządku rzeczy. Jak twierdziła Plater-Zyberkówna, w swoim reportażu zdawała tylko sprawozdanie $z$ tematu goracego, $z$ „uczynionych w podróży spostrzeżeń i obserwacji” ${ }^{48}$. Co prawda, nie nazwała swojej opowieści reportażem, ale budujac ją z przytaczanych wydarzeń, sytuacji, rozmów, notatek i zapisek, wypełniała założenia tego gatunku piśmiennictwa. Przyznawała, że w podróży pędziła i goniła za podjętym tematem, gotowa wraz ze swoją współtowarzyszka „niemal każdy kamień na drodze odwrócić, aby zajrzeć co pod nim?"49. Mówiąc językiem współczesnych reporterów, chciała zobaczyć, co było „pod powierzchnią wydarzeń”50. $Z$ ich własna interpretacja zapoznawała czytelników „Kroniki Rodzinnej”.

Swój tekst zakończyła pointa, że szkoły gospodarcze najbardziej potrzebne sa dla kobiet $z$ przeciwległych biegunów hierarchii społecznej: wiejskich gospodyń i przedstawicielek ziemiańskiej arystokracji. Pierwszym gwarantować miały szacunek dla pracy i podejmowanie jej w sposób rozumny i nowoczesny. Drugie pracy tej miały nauczyć, włączyć w ratowanie majątków, przygotować do roli mądrych i uczciwych pracodawczyń oraz administratorek i zarządczyń majątków własnych rodzin. Takim przesłaniem Plater-Zyberkówna kończyła swoją relację podróżniczą i jednocześnie żegnała się z czytelnikami „Kroniki Rodzinnej”, składając rezygnację

47 Ibidem, s. 791.

48 Tydzień spędzony $w$ Czechach..., nr 20, s. 663.

49 Wrażenia $z$ wycieczki gospodarczej po ks. Poznańskiem przez C.P.Z., KR 1899, nr 12, s. 393.

50 M. Szczygieł, W. Toch man, Reportaż-opowieść o tym, co wydarzyło sie naprawde, [w:] Biblia dziennikarstwa, red. A. Skworz, A. Niziołek, Kraków 2010, s. 295. 
$z$ funkcji redaktorki naczelnej i wydawczyni pisma ${ }^{51}$. Nie zrywając $z$ nim współpracy, swoją decyzję wyjaśniała nadmiarem obowiązków, co wiązać się mogło nie tylko $z$ zaangażowaniem w działalność prowadzonych przez nią szkól, lecz także $z$ podejmowaniem nowych wyzwań, wpisanych już w XX stulecie ${ }^{52}$.

\section{Bibliografia}

\section{Ź RódeA ARChIWALNE}

Archiwum Posłanniczek w Konstancinie-Jeziornie

J. Chudzyńska, Pamiętnik, bez. sygn.

\section{Prasa}

Na stoku gór tyrolskich. Obronny zameczek pod Linzem. (Z wycieczki gospodarczej) napisała C.P.Z., „Kronika Rodzinna” 1899, nr 16, s. 533-536.

Na stoku gór tyrolskich. Obronny zameczek pod Linzem. (Z wycieczki gospodarczej) napisała C.P.Z. (Dokończenie), „Kronika Rodzinna” 1899, nr 17, s. 558-560.

Paryż $i$ jego okolice (Z wycieczki gospodarczej) przez C.P.Z., „Kronika Rodzinna” 1899, nr 13, s. 435-440.

Tydzień spędzony w Czechach. Napisała C.P.Z., „Kronika Rodzinna” 1899, nr 19, s. 630-632.

Tydzień spędzony w Czechach napisała C.P.Z. (Dalszy ciag), „Kronika Rodzinna” 1899, nr 20, s. 659-663.

Tydzień spędzony $w$ Czechach napisała C.P.Z. (Dalszy ciag), „Kronika Rodzinna” 1899, nr 22, s. 725-729.

Tydzień spędzony $w$ Czechach napisała C.P.Z. (Dokończenie), „Kronika Rodzinna” 1899, nr 24, s. 789-793.

Wrażenia z wycieczki gospodarczej po ks. Poznańskim, Niemczech, Francji, Czechach. Cel podróży - Dobrojewo - Borejowice [właść. Bożejowice], „Kronika Rodzinna" 1899, nr 1, s. 15-18.

Wrażenia z wycieczki gospodarczej po ks. Poznańskim, Niemczech, Francji, Czechach. Dalszy ciag, „Kronika Rodzinna” 1899, nr 2, s. 45-48.

${ }^{51}$ Nowym redaktorem pisma został Stanisław Pawiński, a jego wydawca - ks. Hipolit Skimbrowicz. W kolejnych latach przy zmianach redakcji „Kronikę Rodzinną" przekształcano w czasopismo popularne, którego wydawcą od 1905 r. był ks. M. Godlewski, a redaktorem - działacz katolicki Adam Lach Szymański, który powracal do literackich ambicji periodyku $z$ zachowaniem jego religijno-społecznego charakteru. Ostatni numer „Kroniki Rodzinnej” ukazał się w 1915 r.

${ }^{52}$ Problemom szeroko ujmowanej aktywności C. hr. Plater-Zyberkówny poświęcona jest monografia przygotowywana przez autorkę tego tekstu. 
Wrażenia z wycieczki gospodarczej po ks. Poznańskim, Niemczech, Francji, Czechach. Dalszy ciag, „Kronika Rodzinna” 1899, nr 3, s. 82-85.

Wrażenia z wycieczki gospodarczej po ks. Poznańskim, Niemczech, Francji, Czechach. Przez C.P.Z. Dalszy ciag. Hanower. Hodowla drobiu, mleczarnia, „Kronika Rodzinna" 1899, nr 5, s. 147-151.

Wrażenia z wycieczki gospodarczej po ks. Poznańskim, Niemczech, Francji, Czechach przez C.P.Z. Szkoła gospodarcza w Alzay pod Moguncja, „Kronika Rodzinna" 1899, nr 7, s. 227-231.

Wrażenia z wycieczki gospodarczej po ks. Poznańskim, Niemczech, Francji, Czechach przez C.P.Z. (Dalszy ciag), „Kronika Rodzinna” 1899, nr 8, s. 256-259.

Wrażenia z wycieczki gospodarczej po ks. Poznańskim, Niemczech, Francji, Czechach przez C.P.Z. (Dalszy ciag). Moguncja, „Kronika Rodzinna” 1899, nr 9, s. 288-291.

Wrażenia $z$ wycieczki gospodarczej po ks. Poznańskim, Niemczech, Francji, Czechach przez C.P.Z. (Dalszy ciag), „Kronika Rodzinna” 1899, nr 10, s. 328-331.

Wrażenia z wycieczki gospodarczej po ks. Poznańskim, Niemczech, Francji, Czechach przez C.P.Z. (Dalszy ciag), „Kronika Rodzinna” 1899, nr 11, s. 362-365.

Wrażenia z wycieczki gospodarczej po ks. Poznańskim przez C.P.Z., „Kronika Rodzinna” 1899, nr 12, s. 391-394.

\section{OpRacowania}

Dzieje Śremu, red. S. Chmielewski, Warszawa-Poznań 1972.

Chyra-Rolicz Z., Pionierki $w$ nowych zawodach na poczatku XX wieku, [w:] Kobieta i edukacja na ziemiach polskich $w$ XIX i XX w. Zbiór studiów, t. II, cz. 2, red. A. Żarnowska, A. Szwarc, Warszawa 1992, s. 221-236.

Czachowska K., Generałowa Jadwiga Zamoyska (1831-1923). Życie i dzieło, Poznań 2011.

Górski T., Plater-Zyberk Cecylia, [w:] Polski słownik biograficzny, t. XXVI, Kraków 1981, s. 693-694.

Kamiński D., Barbara z Mańkowskich Kwilecka - wybitna Wielkopolanka, „Wiadomości Ziemiańskie" 2017, nr 71, s. 82-88.

Kobieta i media. Studia $z$ dziejów emancypacji kobiet, red. P. Perkowski, T. Stegner, Gdańsk 2009.

Kostrzewska M.E., Szkolnictwo gospodarczo-rolnicze ziemianek Królestwa Polskiego na przełomie XIX i XX w. Między tradycja a nowoczesnościa, [w:] $Z$ dziejów polskiej kultury $i$ oświaty od średniowiecza do początków XX wieku, red. K. Jakubiak, T. Maliszewski, Kraków 2010, s. 145-161.

Kostrzewska M.E., Ziemianki Królestwa Polskiego a gospodarka. Koncepcje i empiria (przełom wieków XIX i XX), „Studia Maritima” [Szczecin] 2015, t. XXVIII, red. Z. Anusik, R. Gazińsk, s. 295-315.

Lesisz B., Polskie czasopisma religijno-społeczne w XIX w., Warszawa 1988.

Mattelart A., Mattelart M., Teoria komunikowania, Warszawa 2001.

Mazurek H.M., Powstanie i rozwój ukrytych zgromadzeń bł. Honorata Koźmińskiego w latach 1874-1908, Sandomierz 2009. 
Molik W., Przekształcanie się wielkopolskiego szlachcica $w$ ziemianina - uspołecznionego farmera $w$ XIX $i$ na poczatku XX w., [w:] Ziemiaństwo wielkopolskie. $W$ kręgu arystokracji, red. A. Kwilecki, Poznań 2004, s. 24-44.

Molik W., Ziemianki wielkopolskie $w$ codziennych zajeciach gospodarczych i $w$ pracy społecznej $w$ drugiej połowie XIX i na poczatku XX wieku, [w:] Kobieta i kultura życia codziennego wiek XIX i XX. Zbiór studiów, t. V, red. A. Żarnowska, A. Szwarc, Warszawa 1997, s. 181-190.

Sikorska-Kowalska M., Kwestia kobieca $w$ świetle programu społecznego „Kroniki Rodzinnej” Aleksandry Borkowskiej (1867-1872), „Acta Universitatis Lodziensis", Folia Historica 61, 1998, s. 17-32.

Szczygieł M., Tochman W., Reportaż-opowieść o tym, co wydarzyło się naprawde,, [w:] Biblia dziennikarstwa, red. A. Skworz, A. Niziołek, Kraków 2010, s. 294-306.

Vošahlikková P., Pozycja społeczna i prestiż kobiety pracujacej zawodowo $w$ Czechach na przełomie XIX i XX wieku, [w:] Kobieta i praca. Wiek XIX i XX. Zbiór studiów, t. VI, red. A. Żarnowska, A. Szwarc, Warszawa 2000, s. 255-266.

Wojtak M., Gatunki prasowe, Lublin 2004.

Ziemiaństwo na Lubelszczyźnie IV. Ziemianie w podróży, t. I-II, red. H. Łaszkiewicz, Lublin 2010.

Ewelina Maria Kostrzewska

\section{A reportage at the end of the century. European economic journeys of Countess Cecylia Plater-Zyberk in the light of the „Kronika Rodzinna” (1899)}

$\mathrm{T}$ he article was prepared on the basis of the „Kronika Rodzinna”, a biweekly published from 1867 in Warsaw. It was addressed to the gentry and intelligentsia, had a literary-social, as well as diary-travel character and often described the so-called feminine issues. During its existence there were program changes. After ideological disputes of the eighties of the $19^{\text {th }}$ century, editors focused on matters related to the household and education. As they followed a moderate mainstream movement of women, the professional education and activity of the latter were promoted by them.

In 1899, Countess Cecylia Plater-Zyberk became the chief editor and the publisher of the magazine. She assimilated landowners', conservative ideals with an intelligent model of an open Catholicism. During an almost one-year of her cadency, the „Kronika Rodzinna” was transformed into a popular „Czasopismo dla Rodzin Katolickich”. The editor herself inaugurated and ended her functions in a series of travel reports.

Using such a modern form of journalistic report, she entered the hard-to-reach for women world of media, professional work, as well as of independent fast travels. While bringing to the common denominator the search for female economic schools in Europe, she was reporting on their civilizational condition. In the descriptions saturated with religious axiology, she presented the readers with her own reflections and social contexts of women's emancipation. 
In a travel reportage she returned to the Polish ground with an idea of a social solidarity; a reconciliation of women's aspirations with religion. The social bond was to join in a special way women from the landowners' elites and peasant villages, while economic schools were to open to them fields of different activities and work. According to the rules of a press reportage, the story of Plater-Zyberk revealed the European reality of the late 19th century in her subjective images seen from the perspective of an aristocrat and the chief-editor of the Catholic „Kronika Rodzinna”.

Keywords: Catholic magazines, „Kronika Rodzinna”, reportage, Countess Cecylia Plater-Zyberk, the Kingdom of Poland's press, travel, economic schools, Europe. 